\title{
THE DEARTH OF STANDARD ANATOMICAL TERMINOLOGIES IN YORÙBÁ LANGUAGE: Butchers' terminologies to the rescue?
}

\author{
Olajuyin OA ${ }^{1}$, Olajide $\mathrm{TG}^{2}$, Akanbi TA ${ }^{3}$, Ikotun $\mathrm{RO}^{3}$ \\ 1. Department of Ear, Nose and Throat, Ekiti State University Teaching Hospital and \\ Department of Anatomy, College of Medicine, Ekiti State University, Ado-Ekiti, Ekiti State, \\ Nigeria ${ }^{1}$. \\ 2. Department of Ear, Nose and Throat, Federal Teaching Hospital, Ido - Ekiti and Afe \\ Babalola University, Ado - Ekiti, Ekiti State, Nigeria². \\ 3. Department of Linguistics and Nigerian Languages, Ekiti State University, Ado - Ekiti, Ekiti \\ State, Nigeria ${ }^{3}$
}

Correspondence to Olajuyin O.A Consultant Ear, Nose \& Throat Surgeon, Associate Lecturer in Anatomy and Medico-linguistic Researcher, Department of Ear, Nose and Throat Surgery, Ekiti-State University Teaching Hospital and Department of Anatomy, College of Medicine, Ekiti State University, Ado-Ekiti, Ekiti-State, Nigeria. Tel: +234-8035769839. E-mail: oyebanjiolajuyin@yahoo.com

\begin{abstract}
The need to replace foreign-language medical terms with indigenous terms has prompted researchers to search for indigenous equivalents of the foreign medical terms. This study which focused on the dearth of standard anatomical terminologies in Yorùbá language was an attempt to examine the adoptability of butchers' terminologies as descriptive anatomical terms for human abdomino-thoracic organs. Practising butchers in the South West Nigeria were interviewed on their terminologies for cow's abdomino-thoracic organs and the basis for each terminology. The butchers' terminologies, in Yorùbá language were critically appraised for adoptability as anatomical terms for human abdomino-thoracic organs. The study observed that cow's abdomino-thoracic organs were grossly similar to those of humans. Majority (65\%) of the cow's abdomino-thoracic organs are named by the butchers' in traditional Yorùbá terminologies. The butchers' terminologies were etymologically derived based on pre-existing concepts similar to the modern terminologies derived from the ancient Greek and Latin words. About $25 \%$ of the butchers' terminologies were the same with some human anatomical terminologies which were in use by the health care professionals. The terminologies concur with the cultural attitudes of the Yorùbá with reference to the private parts of the human body and majority ( $80 \%)$ of the butchers' terminologies is simple and familiar to the people. Given these characteristic features, we concluded that the butchers' terminologies are strongly adoptable as descriptive anatomical terms for human abdomino-thoracic organs and may resolve the dearth of standard anatomical terminologies in Yorùbá language. The findings may form a baseline for future studies on the translation of anatomical terminologies to Yorùbá language.

Key words: Anatomical terms; Butchers terms; Abdomino-thoracic organs; Yorùbá language.
\end{abstract}

\section{INTRODUCTION}

Medical terminology is by necessity complex. "Understanding the jargon of medicine takes extensive years of education and enculturation" (Swiontkowski, 2015) and "Medical terminology is often one of the most common barriers to a patient's understanding" (Science Direct/Hysteroscopy 2009). To this end, scholars have continued to search for indigenous terms to replace the complex medical terms so as to facilitate scientific communication. According to the World Health Organization (2007), "International standard terminology will greatly expedite scientific communications in traditional 
medicine societies. It is the very first step towards the globalization of traditional medicine". This statement, though speaks of cross border globalization of medical terminologies in traditional medicine, it underscores the importance of medical terminology in all spheres of clinical communication. Fundamentally, the search for indigenous medical terminology is to 'domesticate' the medical terminologies with a view to promote access of monolingual patients to health information. According to Olúbọ̀dé-Sàwè et al (2016), "Healthcare givers may find it useful to replace borrowed terms with indigenous Yoruba terms in order to increase the access of monolingual Yorùbá patients to medical information". Also, as part of the efforts to improve patient's access to health care information, the first part of the Nigerian patients' bill of right (2018) says: "To have access to all relevant information in a language that the patient understands". This was also the purpose of the proposed computerized language translator for DoctorPatient mobile chat (Oladosu, Emuoyibofarhe, 2012). The medico-linguistic technology which is meant to promote access of health care providers to patient's information anywhere and anytime could also improve access of the patient to health care information.

Given these ethical, legal and technological bases of indigenous medical terminologies, the need to translate foreign medical terminologies into a language that the patient understands cannot be overemphasized. As observed, access to health care information in a language that the patient understands would not only improve patient's health but also facilitate the patient's trust of the health care delivery. According to Joanna Hughes (2018), "In an increasingly globalized world, the ability to provide care in a patient's native language offers profound benefits, including everything from increasing safety to facilitating patient trust". Also, Jennifer Powell (2019) remarked: "We have to show patients that we really want to get to know them. That means understanding their background, including the culture and family they grew up in and the language they speak". While efforts to produce an indigenous compendium of medical terminologies are being intensified in other parts of the world, only a modicum of research works on this subject exist in this part of the world. Thus, we embarked on this study to determine the adoptability of the butchers' terminologies as a clue to the dearth of anatomical terminologies in Yorùbá language and to form a baseline for future studies on the translation of medical terminologies into Yorùbá language.

Over the years, medical terminologies had undergone evolution. According to-Pierre Sprumont (2016), anatomical names had evolved from the pre-historical times when humans had no handwriting until when printing became a worldwide activity. With the advent of handwriting, early Egyptians and Mesopotamians were among those who began to give specific names to parts of the body (Pierre Sprumont, 2016). However, Greeks were the founders of rational medicine (László Répás, 2013) hence were the first to create the roots of most medical terminologies. As the Greek medicine subsequently migrated to Rome at an early date, many Latin terms crept into its terminology (László Répás, 2013). Ever since the Greek and Latin-derived terminologies had continued to burrow into cross-border anatomical landscape. In a bid to 'domesticate' the anatomical terminologies, individual anatomical societies are being encouraged to develop anatomical terminologies in their own language. This opinion was shared by the Bear-boat Software when it remarked, "Individual international anatomic societies are encouraged to create parallel lists of anatomical terminologies in their own language"

However, terminology creation requires knowledge of the various components and dynamics of the target language and its related features. In the Yorùbá language, for instance, there exist metaphors (OlúbọddéSàwè et al 2016), code-mixing and linguistic borrowing (Ikotun, 2006) which are technical components of the Yorùbá language. Important to note however is the need to create the anatomical terminologies in a way that would facilitate patient's comprehension of the proposed terminologies. Thus, in the 
selection process, the terminologist must adopt words that are known and familiar to the people, avoid the use of incongruous or discordant metaphors, code-mixing and linguistic borrowing. With such practice, not only will the patient comprehend the intended terminologies, but also would have access to the health information and become active member of the health care team. "When all members of a team know medical terminology, they can also help the patient learn what those terms mean. Patient education helps patients become a more active part of their care team, leading to improved satisfaction" (Portland Community College, 2017). Thus, in this study, we examined the characteristic features of butchers' terminologies to see if they fulfill the criteria for adoptability as anatomical terminologies in Yorùbá language for human abdomino-thoracic organs.

\section{MATERIALS AND METHODS}

This was a prospective study of practising butchers in selected abattoirs in the Yorùbáspeaking States, South Western Nigeria. The butchers were selected by multistage sampling technique. The geopolitical attributes of the population were used for stratification. This consists of the States, Senatorial districts and local government areas. The sample size was obtained in proportion to the number of local government areas and population density of the abattoirs. All the selected butchers were versed in Yoruba language. To ensure that the abdomino-thoracic organs of their cows were met in-situ, the butchers were interviewed at the point of slaughtering the cows. At the onset of the interview, the purpose of the study was explained to each butcher and verbal consent was sought from each butcher. Only those who consented to participate were included in the study. Each butcher was interviewed separately for the terminologies of the cow's abdomino-thoracic organs in Yorùbá language.

The information sought included biodemographic data, years of practicing the trade, previous abattoirs and language spoken, the butchers' terminologies for the cow's abdomino-thoracic organs in Yorùbá language and basis for each terminology. These were noted and recorded in the study pro-forma form. For completeness, extraabdomino-thoracic organs such as the tongue and genitals that relate directly with the abdomino-thoracic organs were included in the study. Samples of the abdomino-thoracic organs were bought and shown to the general public for identification in a double-blind study. Excluded from this study were the upper limb, lower limb, thoracic cage, abdomino-pelvic wall and perineum. These were deferred as the subject-matter for future studies. The analytical process used in this study seeks to answer one basic question: (i). Do the butchers' terminologies fulfil the criteria for adoption as descriptive anatomical terms for human abdomino-thoracic organs? The results were descriptively analyzed using Statistical Programme for Social Sciences (SPSS) software version 17.0 (SPSS Inc., Chicago 2008) and level of significance was set at $\mathrm{P}<0.05$.

\section{RESULTS}

In all, 168 butchers participated in the study. There were 162 males and 6 females given a male to female ratio of $27: 1$. The male preponderance of the ratio is informed by the male dominance of the butchery trade in our own setting. Their ages range from 26 years68 years (mean = 34 \pm 6.2 years) and practicing years range from 7-32 years. 
Fifteen $(8.9 \%)$ of the butchers had previously been practising elsewhere and had just relocated to the study locale. We observed that the cow's abdomino-thoracic organs were grossly similar to those of humans. The organs were divisible into respiratory, cardiovascular, lymphatic, digestive, urinary and reproductive systems or 'tracts' (Table 1). Majority (65\%) of the cow's abdominothoracic organs were named by the butchers in traditional Yorùbá terminologies. Other organs such as the prostate perceived by the butchers to be insignificant were jettisoned hence unnamed. The terminologies were etymologically similar in concept to the terminologies derived from the Greek and Latin roots. Some of the butchers' terminologies are the same with some anatomical terminologies used in humans (Table 2). This constitutes $25 \%$ of the butchers' terminologies (Figure 1). Most $(80 \%)$ of the butchers' terminologies were known to the people.

Table 1 shows the anatomical terminologies and butchers' terminologies in Yorùbá language

\begin{tabular}{|c|c|c|}
\hline $\mathrm{S} / \mathrm{N}$ & Anatomical terminologies & Butchers' terminologies \\
\hline & Respiratory tract & Ojú òpó èémí \\
\hline 1 & Nose & Imú \\
\hline 2 & Lungs & Fùkù \\
\hline 3 & Diaphragm & Ėdọ̀ fóró \\
\hline 4 & Trachea & Gò-gò-ń-gò \\
\hline & Cardiovascular tract & Ojú òpó èjẹ \\
\hline 5 & Heart & Ọkàn \\
\hline & Lymphatic tract & Ojú òpó oje funfun \\
\hline & Spleen & Abá \\
\hline 6 & Digestive tract & Ojú òpó oúnjẹ \\
\hline 7 & Tongue & Ahọ́n \\
\hline 8 & Oesophagus & Ònà ọ̀fun \\
\hline 9 & Stomach & Ikùn \\
\hline 10 & Liver & Èdọ̀ \\
\hline 11 & Gall bladder & Òró-ǹ-ro \\
\hline 12 & Large intestine & İfun gbòòrò \\
\hline 13 & Small intestine & İfun tóóró \\
\hline 14 & Rectum & Abọ́dií \\
\hline 15 & Anus & Fùrọ̀ \\
\hline & Urinary tract & Ojú òpó ìtò \\
\hline 16 & Kidney & Kíndinnrín \\
\hline 17 & Urinary bladder & Àpò ìtọ \\
\hline 18 & $\begin{array}{l}\text { Male reproductive system } \\
\text { Testes }\end{array}$ & $\begin{array}{l}\text { Èyà fún ọmọ bíbí lókùnrin } \\
\text { Kórópọ̀n }\end{array}$ \\
\hline & Female reproductive system & Ẹà fún ọmọ bíbí lóbìnrin \\
\hline 19 & Uterus & Ilé ọmọ \\
\hline 20 & Vagina & Ojú ara \\
\hline
\end{tabular}


Table 2 shows the butchers' terminologies that tally with some terminologies in human beings

\begin{tabular}{|l|l|l|l|}
\hline S/N & Source Terms & Butchers' Terminologies & Human Terminologies $^{\dagger}$ \\
\hline 1 & Rectum & Abódií & Abódií / Ilé ìgbẹ́ \\
2 & Anus & Fùrọ̀ & Fùrọ \\
3 & Urinary bladder & Àpò ìtọ & Àpò ìtọ / Ilé ìtọ \\
4 & Uterus & Ilé oọmọ & Ilé ọmọ \\
5 & Vagina & Ojú ara & Ojú ara / Òbò \\
\hline
\end{tabular}

Olúbọdé-Sàwẹ̀ et $\mathrm{al}^{\dagger}$

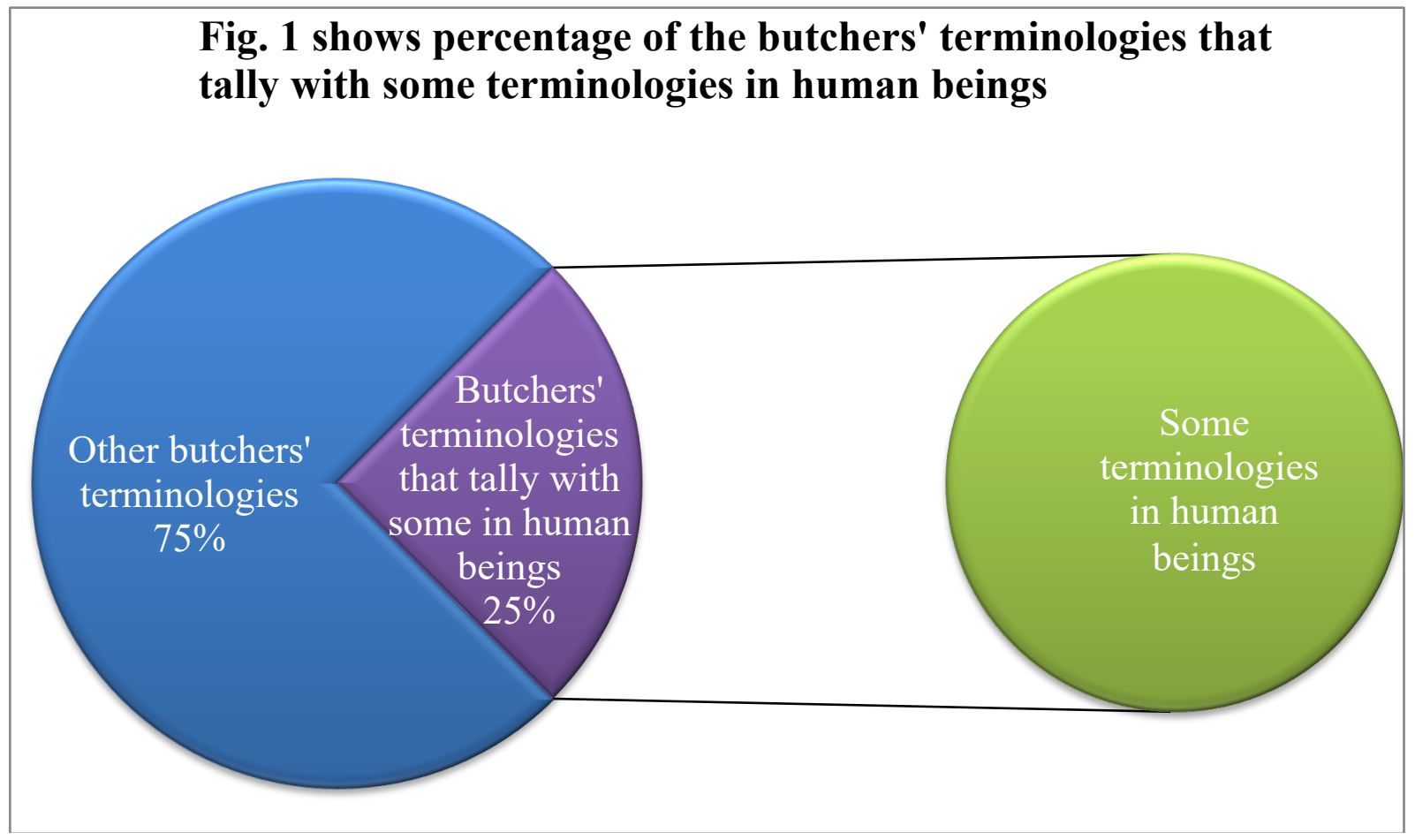

\section{DISCUSSION}

The need to replace foreign-language medical terms with indigenous terms has prompted researchers to search for indigenous equivalents of the foreign medical terms. This study which focused on the dearth of anatomical terminologies in Yorùbá language was an attempt to examine the adoptability of butchers' terminologies as descriptive anatomical terms for human abdominothoracic organs. As observed, the cow's abdomino-thoracic organs are comparatively similar to those in humans. This finding concurs with the report of Prezi (2015) that the anatomy of humans and cows are comparatively similar. Also observed was that majority $(65 \%)$ of the cow's abdominothoracic organs were named by the butchers in traditional Yorùbá terminologies. Although, the terminologies given to most of the organs are the same across board, there were variations in the terminologies given to some of the organs by the butchers. For example, the intestine was termed Ifun (Intestine) by some butchers and Inú-Eran (Internal organ) by others. While the former is specific, the latter is non-specific. In such circumstance, the terminologies with the highest frequency (mode) were selected as the preferred term. In this case, Ifun (Intestine) was the mode and more specific hence was adopted a term for the intestine. Furthermore, it was noted that some terminologies were not properly classified. For example, the intestines were not differentiated into large and small with the butchers' terminologies. In this case, we did the needful by adopting the Yorùbá words 
Gbòò and Tóóró being descriptive of the relative large and small sizes of the intestinal lumen, a feature that forms the basis for classifying the intestine into large and small. In Lexical structuring however, the words large and small that precede 'intestine' in the source terms come after 'intestine' in the Yorùbá translation. That is; the words large intestine and small intestine now become Ifun Gbòòo and İfun Tóóró in the Yorùbá versions. This is in concordance with the rule of word agreement in the language of medical terminology. According to Wikipedia (2019), medical terminology roots generally go together according to language.

Some of the butchers' terminologies in this study seemed to have been generated based on physical and physiological attributes of the target organs. For example, the gallbladder is termed Oró- $\dot{r}$-ro in the butchers' language. The study revealed that the organ is so named because it functions as the reservoir of bitter fluid (bile). In the Yorùbá orthographic translation, bitter substance is described by a word that contains the element 'ro' hence the term; Oró-ri-ro. This is supported by finding 'ro' as a common 'factor' in the following Yorùbá words: İkorò (bitterness), Ewúro (bitter leave), Óro (Wild mango), Orógbó (bitter kola) and Dóńgóyárò (Neem leaves), all which are inherently bitter and together with the Óró-in-ro (gallbladder) are onomatopoeic. It therefore shows that the butchers' terminologies in this study were not created arbitrarily but strategically derived based on a pre-existing concept. This is similar to the principle of the derivation of anatomical terms from the Greek and Latin words as noted by Learning Assistance Center. It must be noted however that; although, substances with bitter taste have 'ro' as a key syllable in their names, it is not all substances with a key syllable 'ro' in their names that have bitter taste. As we all know, birds fly, it is not everything that flies that is bird. Another characteristic feature of the butchers' terminologies in this study is the existence of some terms in composed words. Example is Ọnà ọfun; the Yorùbá equivalent of the term, 'Oesophagus'. In the study of Olúbọ̀dé-Sàwẹ et al (2016), the use of composed terms were noted as an important strategy. As remarked; "In Yorùbá term creation, composition is a very productive strategy". Again, the composed terms as noted in the present study are based on specific concept which may involve describing the target organ with reference to its function, location, appearance or resemblance to a known object. In the case of Ònà ôfun, the word 'Óna' implies route or pathway while 'ófun' means throat. Thus, the term 'Ónà ófun' describes the oesophagus as a pathway or route in the throat. Since the throat is used for swallowing, then, the term 'Ònà ôfun' describes the oesophagus as a route in the organ of swallowing. This strategy of term creation in Yorùbá language describes not only the site but also the function of the target organ.

The use of borrowed terms as butchers' terminologies was another feature noted in this study. Example is Kíndinrín, borrowed from the source term 'Kidney'. The characteristic features of this type of term in Yorùbá language are: both the borrowed term and the term borrowed have the same consonant initial and syllable hence phonetically similar. As noted, Kíndinrín and 'Kidney' have the same consonant initial ' $k$ ' and phonetically have the same initial syllable, 'ki'. This strategy concurs with the observation of İkộtún (2006) that the Yorùbá language speakers adopt English words in agreement with the English morphological structure in their utterances. It also agrees with findings of Olúbọdé-Sàwè et al (2016), where the terms: 'Tube' (Fallopian) and 'Pubic' (Bone) were translated into Yorùbá language as 'Túúbi' and 'Púbiis' respectively. A major advantage of borrowed term is; easy comprehension by a physician having had knowledge of the source term. For instance, a physician with knowledge of kidney would find easier to comprehend Kindinrín as a Yorùbá anatomical term. Other benefit of borrowed terms is the availability of ready-made materials (source terms) for adaptation into the target language. It is interesting to note that some of the butchers' terminologies in this study are in existence with some human anatomical terms (Table 2). Also of note was 
that the concurrent anatomical terms were already in use by the health care professionals. According to Olúbọ̀dé-Sàwè et al (2016), the terms, mainly in the area of reproductive health were used by the health care professionals in Akure, South West Nigeria to describe obstetric-related organs and events. However, it could not be ascertained if these anatomical terminologies were humans or butchers in origin. This notwithstanding, it was noted that the butchers' terminologies seemed to reflect the cultural perception of the Yorùbá about some parts of the body in contrast to findings of Olúbọ̀dé-Sàwè̀ et al. As noted, Ojú ara was consistently used by the butchers to describe the vagina whereas in the study of OlúbòdéSàwè et al (2016), Óbò was considered an optional term (Table 2). Although, Óbò is the Yorùbá term for vagina, it is culturally obscene among the Yorùbá to refer to vagina as Óbò in the public domain. Even, doctors would rather speak of Ojú ara than Obò when educating a Yorùbá woman about her private part. This underscores how revered the private part of a woman is to the Yorùbá. Although, as a metaphor, Ojú ara (eye-ofbody) may be linguistically incongruous, it is preferred to $\dot{O} b \dot{o}$ because of its euphemistic connotation. It is therefore important to note that sometimes in Yorùbá term creation; it might be difficult to strike a balance between cultural conformity and linguistic concordance. In such instance, it may be fair to veer towards the linguistic incongruity than cultural vulgarity. This probably was the basis for the Ojú ara used for vagina by the butchers in their terminologies as noted in this study.

Of interest in this study was the wide knowledge of the butchers' terminologies among the people. As the study shows, $80 \%$ of the butchers' terminologies are known to the people. Although, the reason for this wide knowledge could not be ascertained, it could be that the butchers, over the years, have been trading with the people using their anatomical terminologies. Thus, the commercial interactions over the years could have cross-fertilized the people with the knowledge of the butchers' terminologies.
This is significant because such a good knowledge would facilitate comprehension of any proposed terminologies among the people. As noted by experts, the purpose of 'domesticating' anatomical terminologies is to facilitate patient-physician clinical communication. This was the view of Olúbọddé-Sàwẹ̀ et al (2016) when she remarked: "It must be noted that medical or other technical terminology in Yorùbá or any other indigenous languages is not created so that the specialists can communicate with one another, since they do their specialist interactions in another language. They are meant to facilitate communication with nonspecialists". From this assertion, it is obvious that a golden rule is to use known and familiar words as anatomical terminologies for easy comprehension in a target language. This was fulfilled by the butchers' terminologies in this study and makes them strongly adoptable as descriptive anatomical terminologies for human organs.

In conclusion, this study observed that cow and human abdomino-thoracic organs are grossly similar. Majority (65\%) of the cow's abdomino-thoracic organs were named by the butchers in traditional Yorùbá terminologies. The terminologies were etymologically derived based on pre-existing concept similar to the modern terminologies derived from the ancient Greek and Latin words. About $25 \%$ of the terminologies are the same with some anatomical terminologies in humans which were already in use by the health care professionals. The butchers' terminologies concur with the cultural attitudes of the Yorùbá with reference to the private parts of the human body and majority (80\%) of the butchers' terminologies are simple and familiar to the people. Given these characteristic features, the butchers' terminologies are strongly adoptable as descriptive anatomical terminologies for human abdomino-thoracic organs and may resolve the dearth of standard anatomical terms in Yorùbá language. The findings in this study can be used as a baseline for future studies on the translation of anatomical terminologies into Yorùbá language. 
Conflicts of Interest: Nil.

Grants and support: Nil, this is a self-sponsored project

\section{REFERENCES}

1. Bearboat Software. Terminologia Anatomica: In Outline Form. Accessed from: http://bearboat.net/TerminologiaAnatomica/TerminologiaAnatomica.html on 18-10-2019.

1. Consumer Protection Council. Patients' Bill of Rights. 2018. Accessed from: http://fccpc.gov.ng/uploads/files/patients-bill-of-rights-full-version.pdf on 03-11-2019.

2. Ikọttún R.O. 2006. Code-mixing and Linguistic Borrowing in Yorùbá'. Adó journal of languages and linguistics. 1(1) $66-88$

3. Powell J. 2019. Overcoming language, cultural barriers in health care. Accessed from: https://hhma.org/blog/overcoming-lanquage-cultural-barriers- in-health-care/ on 03-112019.

4. Hughes J. 2018. Why Medical Students Should Learn Languages. Accessed from: https://www.healthcarestudies.com/article/why-medical-students-should-learn-languages/ on 03-11-2019.

5. Répás L. 2013. Introduction to medical terminology, the main sources of medical terminology. In: Basics of Medical Terminology Latin and Greek origins, Textbook for $1^{\text {st }}$ Year Students of Medicine. Debrecen, Hungary. 5-9.

6. Oladosu J.B, Emuoyibofarhe J.O. 2012. A Yorùbá-English Language. Translator for DoctorPatient Mobile Chat Application. International Journal of Computers and Applications. 34 (3):149-156.

7. Olubode-Sawe F.O, Inya O. 2016. Metaphors in Medical Terminology and implication for Terminology Development. In: New Findings in West African Languages and Literature. The West African Linguistic Society (Pub). Oye Tawio, Lendzemo Constantine Yuka (Eds), pp.329-341

8. Sprumont P. 2016. Anatomical Terms: Towards Development of terminologies (terminogenesis). Eur. J. Anat. 20 (3):249-280.

9. Portland Community College. 2017. The Importance of Medical Terminology in the Healthcare Field. http://climb.pcc.edu/blog/the- importance-of-medical-terminology-in-thehealthcare-field

10. Prezi. 2015. Anatomy and Physiology of humans compared to cows. Accessed from: https://prezi.com/eifuhzm4e3rp/anatomy-and-physiology-of- humans-compared-to-cows/ on 18-10-2019

11. Science Direct/Hysteroscopy. 2009. Medical Terminology - an overview. Accessed from: https://www.sciencedirect.com/topics/nursing-and-health-professions/medical-terminology. on $18-10-2019$.

12. Swiontkowski M.F. 2015. Forward. In: A Manual of Orthopaedic Terminology. Accessed from: $\quad$ https://www.sciencedirect.com/topics/nursing-and-health-professions/medicalterminology on 18-10-2019. $8^{\text {th }}$ Ed. Elsevier.

13. WHO. 2007. The WHO International standard terminologies on traditional medicine in the western pacific region. Accessed from: http://www.wpro.who.int/publications/who istrm file.pdf on 27-09-2019.

14. Wikipedia. 2019. List of medical roots, suffixes and prefixes. Accessed from: https://en.wikipedia.org/wiki/List of medical roots, suffixes and prefixes 